\title{
Komunikasi Matematis Siswa dengan Model Pembelajaran Student Facilitator and Explaining Berbantuan Alat Peraga Dinding Diagram (Dinggram) Venn
}

\author{
Nindy Citroresmi Prihatiningtyas ${ }^{1}$, Buyung $^{2}$, Resi Januarsi ${ }^{3}$ \\ STKIP Singkawang, Singkawang, Indonesia \\ nindy.citroresmi@gmail.com ${ }^{1, *)}, 21 . b u y u n g @$ gmail.com $^{2}$, resi.januarsi12389@gmail.com ${ }^{3}$ \\ ${ }^{*}$ Corresponding author
}

\section{Kata Kunci: \\ Student Facilitator and Explaining; Dinggram Venn; Kemampuan Komunikasi; Himpunan}

\begin{abstract}
ABSTRAK
Penelitian ini bertujuan untuk mengetahui pengaruh model pembelajaran Student Facilitator and Explaining berbantuan alat peraga Dingram Venn terhadap kemampuan komunikasi matematis siswa pada materi himpunan di kelas VII SMP Negeri 8 Singkawang. Penelitian ini menggunakan desain Quasi Eksperimental.Populasi dalam penelitian ini adalah semиa siswa kelas VII yang terdiri dari lima kelas yang berjumlah 130 siswa. Sampel diambil dengan teknik purposive sample. Instrumen yang digunakan dalam penelitian ini berupa tes kemampuan komunikasi matematis siswa (posttest), lembar aktivitas dan lembar angket motivasi belajar. Teknik analisis data yang digunakan adalah uji Independent Sample T-Test, uji Effect Size, menghitung rata-rata persentase dari tiga pengamat dan menghitung rata-rata skor motivasi belajar seluruh siswa pada setiap indikator motivasi. Hasil penelitian menunjukkan: (1) terdapat perbedaan kemampuan komunikasi matematis siswa antara kelas yang menggunakan model pembelajaran Student Facilitator and Explaining berbantuan alat peraga dinggram venn dengan kelas yang menggunakan model pembelajaran langsung; (2) pengaruh model pembelajaran Student Facilitator and Explaining berbantuan alat peraga dinggram venn terhadap kemampuan komunikasi siswa tergolong tinggi; (3) aktivitas belajar siswa tergolong sangat aktif; (4) motivasi belajar siswa tergolong sangat tinggi.
\end{abstract}

\section{PENDAHULUAN}

Matematika adalah suatu ilmu pasti yang mendasari daya pikir, membantu serta memajukan manusia dalam kehidupan sehari-hari. Hal ini sependapat dengan Buyung \& Nirawati (2018: 21) bahwa matematika mempunyai arti penting dalam membantu manusia dalam meyelesaikan masalah pada kehidupan sehari-hari. Hal ini juga didukung oleh Hija, Nirawati, \& Prihatiningtyas (2016: 25) yang menyatakan bahwa matematika merupakan ilmu universal yang mendasari perkembangan teknologi 
modern, mempunyai peran penting dalam berbagai disiplin dan memajukan daya pikir manusia. Pentingnya kemampuan komunikasi matematis tercantum Peraturan Menteri Pendidikan Nasional No.22 Tahun 2006 menyebutkan bahwa pembelajaran matematika bertujuan agar peserta didik memiliki kemampuan untuk mengkomunikasikan gagasan dengan simbol, tabel, diagram, atau media lain untuk memperjelas keadaan atau masalah.

Kemampuan komunikasi matematis adalah kemampuan menyampaikan ide (gagasan) matematis, baik secara lisan maupun tulisan. Hal ini dipertegas oleh Rachmayani (2014: 14) menyatakan bahwa komunikasi dalam hal ini adalah tidak sekedar komunikasi secara lisan atau verbal tetapi juga komunikasi secara tertulis. Hal tersebut juga didukung oleh Suliswa, Rosmaiyadi, \& Buyung (2017: 37) yang menyatakan bahwa komunikasi matematika merupakan suatu peristiwa saling hubungan atau dialog yang terjadi dalam suatu lingkungan kelas dimana terjadi pengalihan pesan balik secara tertulis maupun lisan yang berisi tentang materi matematika yang dipelajari di kelas. Menurut Fitriani Dulis (Wahyuni dkk., 2016: 81), kemampuan berkomunikasi merupakan penunjang keberhasilan siswa dalam mempelajari semua bidang studi yang terdapat di sekolah. Komunikasi matematis merupakan salah satu kemampuan yang harus dibekalkan keoada siswa dalam pelajaran matematika. Menurut Prayitno dkk. (2013) dan Wahyuni dkk. (2016: 82) mengatakan bahwa kemampuan komunikasi matematis adalah suatu cara siswa untuk menyatakan dan menafsirkan gagasan-gagasan secara lisan maupun tertulis, baik dalam bentuk gambar, tabel, diagram, rumus atau demonstrasi.

Namun fakta yang terjadi di lapangan kemampuan komunikasi matematis siswa masih rendah, hal ini dibuktikan berdasarkan data hasil prariset pada siswa di SMP N 8 Singkawang. Berdasarkan prariset yang dilakukan hampir seluruh siswa dibawah Kriteria Ketuntasan Minimal (KKM). Dari hasil prariset yang dilakukan pada tanggal 22 Januari 2018, masih terdapat siswa yang kurang aktif dan cenderung pasif dalam belajar. Ketika guru meminta untuk maju ke depan kelas siswa masih kesulitan dalam mengungkapkan gagasannya dalam bentuk tulisan, sehingga aktivitas siswa dalam mengkomunikasikan masih sangat kurang sehingga siswa menjadi kurang aktif.

Dari data hasil prariset yang diperoleh bahwa dari 32 siswa: (1) terdapat 62,5\% atau sekitar 20 siswa yang tidak tepat menuliskan gagasan dalam bentuk notasi himpunan karena siswa hanya langsung mendata anggota dari himpunan tanpa menuliskan huruf A sebagai himpunan dari bilangan prima kurang dari 12 dimana yang seharusnya siswa menuliskan lambang A terlebih dulu sebagai anggota dari A kemudian baru mendata anggota nya, (2) terdapat $75 \%$ atau 24 siswa yang tidak tepat bahkan tidak paham dalam mengekspresikan ide-ide matematika baik dalam bentuk tulisan maupun dalam bentuk gambar, siswa cenderung langsung membuat diagram venn tanpa menggambar himpunan semesta nya, (3) terdapat $78 \%$ atau 25 siswa yang masih kurang tepat dalam menyatakan gagasan dalam bentuk kalimat. Siswa cenderung menjawab sesuai dengan apa yang ia yakini. Berdasarkan prariset yang dilakukan hampir seluruh siswa dibawah Kriteria Ketuntasan Minimal (KKM).

Salah satu solusi untuk meningkatkan kemampuan komunikasi matematis adalah untuk membuat siswa aktif dan termotivasi dalam proses pembelajaran di kelas, guru harus mampu memilih strategi yang sesuai dengan kondisi siswa. Dengan adanya interaksi dalam kegiatan belajar mengajar siswa akan terlatih untuk mengkomunikasikan konsep atau ide-ide matematika yang sedang dipelajari serta akan aktif dalam aktivitas belajarnya. Salah satu model yang digunakan untuk meningkatkan aktivitas belajar yang mempengaruhi keaktifan belajar dan motivasi siswa yaitu dengan menggunakan model Student Facilitator and Explaining (SFE). Model pembelajaran SFE adalah model pembelajaran yang menempatkan siswa yang unggul sebagai tutor sebaya dan fasilitator bagi siswa lainnya. Pada model ini siswa belajar mempersentasikan ide atau pendapatnya pada rekan siswa yang lain, siswa dapat mengeluarkan ide-ide yang ada di pikirannya sehingga lebih dapat memahami materi matematika sesuai dengan pendapat (Wiradnyana, 2014: 58).

Dalam penelitian ini, alat peraga diduga sebagai alat yang dapat mempermudah siswa dalam mempelajari materi pembelajaran. Alat peraga yang dibuat adalah alat peraga Dinggram Venn untuk membantu siswa memahami materi himpunan secara nyata, sehingga pembelajaran matematika di 
kelas tidak akan membosankan dan akan mudah dipahami oleh siswa. Sehingga model pembelajaran SFE berbantuan alat peraga diduga dapat mempengaruhi dan meningkatkan kemampuan komunikasi matematis siswa.

Hasil penelitian yang mendukung paragraf diatas dilakukan oleh Sari (2016) menyatakan bahwa sikap positif dan hasil belajar siswa yang mengikuti pembelajaran dengan metode Student Facilitator and Explaining (SFE) secara signifikan lebih baik dari pembelajaran ekspositori. Adapun menurut Zahra, dkk. (2016: 103) menyatakan bahwa model pembelajaran SFE berbantuan alat peraga kotak imajinasi dapat menghasilkan prestasi belajar yang lebih baik dari model pembelajaran langsung karena pada proses pembelajaran siswa lebih aktif serta siswa mampu mengembangkan potensi individu yang berhasil, kretif, bertanggung jawab, mampu mengoptimalkan dirinya terhadap perubahan yang terjadi. Parera (2015) menyatakan bahwa pembelajaran dengan pemanfaatan papan berpaku(geoboard) mendapat tanggapan yang baik karena hampir $90 \%$ siswa merasa terbantu dengan alat peraga papan berpaku (geoboard) pada materi menghitung luas persegi dan luas persegi panjang.

Dari latar belakang diatas, maka rumusan masalah dalam penelitian ini adalah sebagai berikut: (1) Apakah terdapat perbedaan kemampuan komunikasi matematis antara siswa yang mendapat pembelajaran dengan menggunakan model pembelajaran Student Facilitator and Explaining berbantuan alat peraga dinggram venn dengan siswa yang mendapat model pembelajaran langsung pada materi himpunan? (2) Seberapa besar pengaruh model pembelajaran Student Facilitator and Explaining berbantuan alat peraga dinggram venn terhadap kemampuan komunikasi matematis siswa pada materi himpunan? (3) Apakah aktivitas belajar siswa tergolong aktif setelah diterapkan model Student Facilitator and Explaining berbantuan alat peraga Dinggram Venn pada materi himpunan? (4) Apakah motivasi belajar siswa tergolong tinggi setelah diterapkan model Student Facilitator and Explaining berbantuan alat peraga Dinggram Venn pada materi himpunan?

\section{METODE PENELITIAN}

Dalam penelitian ini Desain penelitian yang digunakan adalah quasi-eksperimental dengan rancangan nonequivalent posttest-only control group design yaitu kelas eksperimen yang menggunakan model pembelajaran Student Facilitator and Explaining berbantuan alat peraga dinggram venn dan kelas kontrol yang menggunakan model pembelajaran langsung. Populasi dalam penelitian ini adalah seluruh siswa kelas VII. Sampel dalam penelitian ini dengan menggunakan teknik purposive sample sebanyak dua kelas, yaitu kelas VII D sebagai kelas eksperimen dan kelas VII E sebagai kelas kontrol. Dengan menggunakan desain penelitian yang dikemukakan oleh Lestari dan Yudhanegara (2015: 136) menggunakan tes akhir atau posstest. Adapun rancangan penelitian dapat dilihat pada Gambar 1.

\begin{tabular}{|lll|}
\hline$R_{1}$ & $X_{1}$ & $O_{1}$ \\
$R_{2}$ & $X_{2}$ & $O_{2}$ \\
\hline
\end{tabular}

Gambar 1. Rancangan Penelitian

Keterangan:

$X_{1}=$ perlakuan (treatment) dengan model pembelajaran Student Facilitator and Explaining berbantuan alat peraga Dinggram Venn

$X_{2}=$ perlakuan dengan model pembelajaran langsung

$O_{1}=$ posttest pada kelas eksperimen

$\mathrm{O}_{2}=$ posttest pada kelas kontrol

$R_{1}=$ kelas eksperimen

$R_{2}=$ kelas kontrol

Instrumen Penelitian Tes kemampuan komunikasi matematis. Bentuk instrumen dari penelitian ini adalah tes uraian (esai). Tes adalah serangkaian pertanyaan atau latihan yang digunakan untuk 
mengukur keterampilan, pengetahuan dan kemampuan atau bakat yang digunakan oleh individu atau kelompok (Siregar, 2014: 125). Teknik observasi langsung untuk mengetahui aktivitas siswa. Pengamatan dilakukan oleh satu orang guru SMP Negeri 8 Singkawang dan dua rekan mahasiswa STKIP Singkawang selama proses pembelajaran pada materi himpunan. Angket adalah instrumen non tes yang berupa daftar pernyataan yang harus dijawab oleh orang yang menjadi subjek dalam penelitian (responden) (Lestari dan Yudhanegara, 2015: 169).

\section{HASIL DAN PEMBAHASAN}

Hasil yang diperoleh dari penelitian ini yaitu, hasil tes kemampuan komunikasi matematis siswa pada model pembelajaran Student Facilitator and Explaining berbantuan alat peraga dinggram venn, hasil aktivitas belajar siswa setelah diterapkan model Student Facilitator and Explaining dan hasil analisis angket motivasi siswa terhadap model pembelajaran Student Facilitator and Explaining berbantuan alat peraga dinggram venn. Hasil tes kemampuan komunikasi matematis siswa diperoleh dari hasil perhitungan nilai posttest. Adapun hasil perhitungan nilai posttest siswa kelas eksperimen dan kelas kontrol disajikan pada Tabel 1.

Tabel 1. Perbedaan Nilai Siswa Kelas Eksperimen dan Kelas Kontrol

\begin{tabular}{ccc}
\hline Statistika & Eksperimen & Kontrol \\
\hline Rata-rata & 82,65 & 61,10 \\
Standar Deviasi & 10,85 & 12,21 \\
Jumlah Siswa & 26 & 25 \\
\hline
\end{tabular}

Secara deskripsi terlihat data skor posttest kelompok kelas eksperimen dan kelas kontrol tidak sama. Maka dari itu untuk selanjutnya akan dilakukan uji perbedaan dua rerata.Selanjutnya dilakukan uji perbedaan rata-rata skor posttest kelas eksperimen dan kelas kontrol, namun sebelumnya rata-rata skor posttest kelas eksperimen dan kelas kontrol dilakukan uji normalitas dan homogenitas variansi data. Adapun rekapitulasi hasil uji normalitas data posttest untuk kelas eksperimen dan kontrol, dapat dilihat pada Tabel 2.

Tabel 2. Rekapitulasi Perhitungan Uji Normalitas

\begin{tabular}{cccccc}
\hline Kelompok & $\mathbf{N}$ & $\begin{array}{c}\text { Taraf } \\
\text { Signifikan }\end{array}$ & $\begin{array}{c}\mathbf{X}^{\mathbf{2}} \\
\text { Hitung }\end{array}$ & $\begin{array}{c}\mathbf{X}^{\mathbf{2}} \\
\text { Tabel }\end{array}$ & Keterangan \\
\hline Eksperimen & 26 & $5 \%$ & 13,195 & 11,07 & Tidak Normal \\
Kontrol & 25 & $5 \%$ & 22,483 & 11,07 & Tidak Normal \\
\hline
\end{tabular}

Pada Tabel 2 terlihat bahwa hasil perhitungan uji normalitas pada kelas eksperimen diperoleh harga $\mathrm{x}^{2}$ hitung $=13,195$, sedangkan dari tabel kritis uji chi-kuadrat diperoleh $\mathrm{x}^{2}$ tabel dengan jumlah sampel sebanyak 26 siswa dan banyak kelas ada 5 dengan taraf signifikan $\alpha=5 \%$ adalah 11,07 . Karena ${ }^{2}$ hitung $>\mathrm{x}^{2}$ tabel maka $\mathrm{H}_{0}$ ditolak dan $\mathrm{H} \alpha$ diterima, artinya data yang berada pada kelompok eksperimen berdistribusi tidak normal. Kemudian pada hasil perhitungan uji normalitas pada kelompok kontrol, diperoleh harga $\mathrm{x}^{2}$ hitung $=22,483$, sedangkan dari tabel kritis uji chi-kuadrat diperoleh $\mathrm{x}^{2}$ tabel dengan jumlah sampel 25 siswa dan banyak kelas ada 5 pada taraf signifikan $\alpha=5 \%$ adalah 11,07 . Karena $\mathrm{x}^{2}$ hitung $>\mathrm{x}^{2}$ tabel maka $\mathrm{H}_{0}$ ditolak dan $\mathrm{H} \alpha$ diterima, artinya data yang berada pada kelompok kontrol berdistribusi tidak normal. Karena data berdistribusi tidak normal maka selanjutnya dilakukan uji Man Whitney U-Test dapat dilihat pada Tabel 3.

Tabel 3. Rekapitulasi Perhitungan Uji Man Whitney U-Test

\begin{tabular}{ccccccc}
\hline Keterangan & $\boldsymbol{n}_{\mathbf{1}}$ & $\boldsymbol{n}_{\mathbf{2}}$ & $\mathbf{U}_{\mathbf{1}}$ & $\mathbf{U}_{\mathbf{2}}$ & $\mathbf{E}(\mathbf{U})$ & $\operatorname{Var}(\mathbf{U})$ \\
\hline Skor & 26 & 25 & 55 & 595 & 325 & 2816,67 \\
$\boldsymbol{Z}_{\text {hitung }}$ & & & & $-4,54$ & & \\
$-\boldsymbol{Z}_{\text {tabel }}$ & & & & $-1,96$ & & \\
\hline
\end{tabular}


Berdasarkan Tabel 3, terlihat bahwa hasil perhitungan nilai $Z_{\text {hitung }}=-4,54$. Berdasarkan kriteria pengujian maka penggunaan model pembelajaran SFE berbantuan alat peraga Dinggram Venn dan model pembelajaran langsung terhadap kemampuan komunikasi matematis siswa dikatakan memiliki perbedaan apabila $Z_{\text {hitung }}<-Z_{\text {tabel }}$ atau $H_{\mathrm{o}}$ ditolak, sebaliknya dikatakan tidak ada perbedaan penggunaan model pembelajaran $S F E$ berbantuan alat peraga Dinggram Venn dan model pembelajaran langsung terhadap kemampuan komunikasi matematis siswa apabila $-Z_{\text {tabel }} \leq Z_{\text {hitung }} \leq$ $Z_{\text {tabel }}$ atau $\mathrm{H}_{\mathrm{o}}$ diterima. Diketahui $Z_{\text {hitung }}<-Z_{\text {tabel }}$ atau $-4,54<-1,96$, maka Ho ditolak. Dapat disimpulkan bahwa terdapat perbedaan kemampuan komunikasi matematis siswa pada materi himpunan kelas VII SMP Negeri 8 Singkawang. Selanjutnya untuk mengetahui seberapa besar pengaruh model pembelajaran $S F E$ berbantuan alat peraga dinggram venn terhadap kemampuan komunikasi matematis siswa, maka digunakan rumus Effect Size. Adapun hasil selengkapnya dapat dilihat pada Tabel 4.

Tabel 4. Rekapitulasi Hasil Uji Effect Size

\begin{tabular}{ccc}
\hline Kelas & Nilai Rata-rata & Standar Deviasi \\
\hline Eksperimen & 80,65 & 10,85 \\
Kontrol & 61,10 & 12,21 \\
\hline Effect Size & \multicolumn{3}{c}{$\mathbf{1 , 7 5}$} \\
Kriteria & \multicolumn{3}{c}{ Tinggi } \\
\hline
\end{tabular}

Berdasarkan perhitungan diperoleh effect size 1,75 . Berdasarkan kriteria effect size maka $=1,75$ berada pada skala $\geq 0,8$ yang artinya kriterianya tergolong tinggi. Hal ini berarti terdapat pengaruh model pembelajaran Student Facilitator and Explaining berbantuan alat peraga dinggram venn terhadap kemampuan komunikasi matematis siswa. Hal ini sejalan dengan penelitian yang dilakukan oleh Sari (2016) yang menyimpulkan bahwa siswa yang mengikuti model pembelajaran SFE lebih baik daripada siswa yang mengikuti pembelajaran langsung. Hal ini terlihat dari skor rata-rata kemampuan komunikasi matematis siswa di kedua kelas tersebut. Dengan demikian hal ini menunjukkan bahwa model pembelajaran SFE berbantuan alat peraga Dinggram Venn berpengaruh signifikan terhadap kemampuan komunikasi matematis siswa. Aktivitas siswa diperoleh melalui lembar aktivitas belajar yang diisi oleh 3 pengamat dengan melakukan teknik observasi langsung. Aktivitas siswa dikatakan baik jika persentase siswa aktif lebih besar daripada jumlah persentase siswa pasif. Adapun rekapitulasi hasil aktvitas belajar siswa dapat dilihat pada Tabel 5.

Tabel 5. Hasil Rekapitulasi Aktivitas Belajar Siswa

\begin{tabular}{ccccc}
\hline No & Kategori Pengamatan & \multicolumn{2}{c}{ Persentase Aktivitas (\%) } & $\begin{array}{c}\text { Rata-rata } \\
\text { Keseluruhan } \\
\text { Persentase }\end{array}$ \\
\cline { 3 - 4 } & Pertemuan 1 & Pertemuan 2 & 81,42 \\
2 & Visual activities & 78,21 & 84,62 & 75 \\
3 & Oral activities & 70,94 & 79,06 & 74,15 \\
4 & Listening activities & 70,51 & 77,78 & 79,11 \\
5 & Writing activities & 75,13 & 83,08 & 77,35 \\
\hline
\end{tabular}

Berdasarkan Tabel 5 dapat diketahui bahwa pada indikator visual activities yang memuat tiga pernyataan, memiliki rata-rata sebesar $81,42 \%$ dengan kriteria aktif. Pada indikator oral activities yang memuat tiga pernyataan memiliki rata-rata sebesar $75 \%$ berada pada kriteria aktif. Pada indikator listening activities yang memuat tiga pernyataan memiliki rata-rata sebesar 74,15\% dengan kriteria aktif. Pada indikator writting activities yang memuat lima pernyataan memiliki rata-rata sebesar $79,11 \%$ pada kriteria aktif. Pada indikator mental activities yang memuat tiga pernyataan memiliki rata-rata sebesar $77,35 \%$ berada pada kriteria aktif. Karena aktivitas siswa secara keseluruhan dikategorikan aktif maka dapat disimpulkan bahwa aktivitas belajar siswa tergolong sangat aktif dengan diterapkannya model pembelajaran Student Facilitator and Explaining (SFE) berbantuan alat peraga Dinggram Venn. Motivasi siswa diperoleh melalui penyebaran angket setelah kegiatan pembelajaran menggunakan model pembelajaran Student Facilitator and Explaining berbantuan alat 
peraga dinggram venn. Model pembelajaran dikatakan berpengaruh terhadap motivasi jika rata-rata motivasi siswa berada pada kategori tinggi atau sangat tinggi. Adapun rekapitulasi hasil angket motivasi siswa dapat dilihat pada Tabel 6.

\begin{tabular}{ccc}
\multicolumn{3}{c}{ Tabel 6. Rekapitulasi Hasil Angket Motivasi Belajar Siswa } \\
\hline Motivasi & Rata-rata & Kriteria \\
\hline Positif & 4,63 & Sangat Tinggi \\
Negatif & 3,98 & Tinggi \\
\hline Rata-rata Keseluruhan & $\mathbf{4 , 3 1}$ & Sangat Tinggi \\
\hline
\end{tabular}

Berdasarkan perhitungan hasil angket motivasi belajar siswa diperoleh hasil rata-rata angket motivasi belajar siswa untuk pernyataan positif berada pada criteria sangat tinggi dan untuk pernyataan negatif berada pada kriteria tinggi. Hal ini membuktikan kekonsistenan terhadap hasil angket motivasi belajar siswa baik untuk pernyataan positif maupun pernyataan negatif yaitu tinggi, dengan rata-rata keseluruhan yang diperoleh berada pada kriteria sangat tinggi. Hal ini sejalan dengan penelitian Nurhayati (2016) yang menyatakan bahwa terdapat perbedaan motivasi yang signifikan antara kelas yang mendapat model pembelajaran $S F E$ dengan kelas yang mendapat model pembelajaran langsung. Ini berarti model pembelajaran $S F E$ berpengaruh besar terhadap motivasi belajar siswa.

Selama pelaksanaan pembelajaran, peneliti menemukan beberapa data penting, diantaranya model pembelajaran SFE memiliki tahap-tahap yang membuat siswa lebih aktif dan lebih dapat berkomunikasi baik dengan guru maupun dengan teman lainnya. Guru tidak sekadar memberikan pengetahuan kepada siswa, melainkan memfasilitasi siswa untuk membangun pengetahuannya sendiri sehingga siswa memiliki pemahaman yang lebih baik terhadap materi himpunan.

Model pembelajaran SFE Proses pembelajaran yang terjadi di kelas eksperimen pada tahap pendahuluan siswa dikondisikan untuk siap belajar dengan melakukan apersepsi yaitu menghubungkan materi yang telah dipelajari sebelumnya dan mengecek pemahaman siswa tentang materi yang akan dipelajari yaitu himpunan kemudian dilanjutan pada tahap 1 dengan menyampaikan informasi kompetensi dan tujuan pembelajaran secara garis besar kemudian pada tahap ini guru juga memotivasi siswa untuk giat belajar. Model pembelajaran SFE dalam penelitian ini dikolaborasikan dengan penggunaan alat peraga Dinggram Venn dan LKS yang dirancang sesuai dengan langkahlangkah pada model pembelajaran SFE, dengan adanya penyampaian informasi belajar dengan menggunakan bantuan alat peraga Dinggram Venn siswa menjadi termotivasi dan tertarik sehingga perhatian siswa dapat terpusat pada pembelajaran.

Pada kegiatan inti tahap 2 yaitu sajian materi, guru memfasilitasi pengetahuan siswa dengan memberikan gambaran materi yang akan dipelajari. Hal ini memacu rasa ingin tahu siswa untuk dapat memahami materi yang akan dipelajari. Kemudian pada tahap 3 yaitu mengembangkan materi, siswa secara berkelompok berdiskusi untuk mengembangkan materi dengan menggunakan bantuan LKS yang telah diberikan sebelumnya. Pada tahap inilah siswa menyadari adanya perbedaan pendapat dalam kelompok sehingga siswa lebih antusias dan aktif dalam mengembangkan pemahaman yang mereka miliki.

Pada tahap 4 yaitu menjelaskan kepada siswa lainnya, masing-masing kelompok harus menunjuk perwakilan untuk mempresentasikan hasil diskusi mereka. Siswa yang pada awalnya hanya mendengarkan penjelasan dari guru sebaliknya berperan sebagai guru. Mereka merasa tertantang untuk menjadi yang paling baik diantara kelompok yang lain, sehingga masing-masing kelompok berusaha mengemukakan keunggulan pendapat mereka tentang konsep yang dipelajari. Hal ini akan memacu komunikasi yang baik antar siswa untuk mengembangkan ide dan menyampaikan pengetahuan yang dimiliki pada siswa lainnya. Pada tahap ini terjadi interaksi antara siswa dengan siswa lainnya yang saling bertukar pendapat dan melengkapi satu sama lain sehingga siswa yang belum mengerti dengan materi yang sebelumnya disampaikan guru akan lebih memahaminya melalui presentasi dan tanya jawab yang dilakukan sesama siswa. 
Selanjutnya pada kegiatan inti tahap 5 yaitu kesimpulan, tahap ini hanya memberikan konfirmasi terhadap presentasi siswa di depan kelas tahap 6 yaitu evaluasi dengan memberikan soal latihan yang dikerjakan secara individu. Pada tahap ini siswa menjadi lebih bersemangat untuk memperbaiki kesalahan sebelumnya, sampai tahap 7 yaitu refleksi, siswa mendapatkan penjelasan lebih lanjut dari guru mengenai hasil presentasi yang telah dilaksanakan. Pada tahap ini juga siswa akan dibantu dengan penggunaan alat peraga Dinggram Venn. Siswa secara bergantian menggunakan alat peraga Dinggram Venn untuk membuktikan kebenaran materi yang telah didiskusikan. Kemudian siswa diberikan soal latihan yang dikerjakan secara individu sebagai evaluasi dari proses pembelajaran yang telah dilaksanakan.

Pada kegiatan penutup siswa bersama-sama menarik kesimpulan dengan bimbingan guru. Adanya model pembelajaran SFE berbantuan alat peraga Dinggram Venn dapat mempengaruhi kemampuan komunikasi matematis siswa dalam proses pembelajaran dan meningkatkan aktivitas serta motivasi siswa dalam belajar.

Dari uraian tersebut, model SFE merupakan satu diantara model yang dapat melatih kemampuan komunikasi matematis siswa dan membantu siswa lebih aktif dalam pembelajaran sehingga siswa menjadi aktif dan termotivasi untuk belajar. Sebelum model $S F E$ diterapkan kemampuan komunikasi matematis siswa dengan indikator (1) kemampuan menyatakan gagasan dalam bentuk notasi atau simbol; (2) kemampuan menyatakan gagasan dalam bentuk gambar; (3) kemampuan menyatakan gagasan dalam bentuk kalimat di kelas VII SMP Negeri 8 Singkawang masih tergolong rendah, aktivitas belajar siswa kurang dan motivasi belajar siswa juga tergolong rendah. Setelah diterapkan model SFE kategori kemampuan komunikasi matematis siswa tergolong tinggi, aktivitas serta tergolong aktif dan motivasi belajar siswa tergolong tinggi.

\section{KESIMPULAN}

Berdasarkan hasil penelitian dan pembahasan secara keseluruhan, maka dapat ditarik simpulan sebagai berikut: Terdapat perbedaan kemampuan komunikasi matematis antara siswa yang mendapatkan model pembelajaran Student Facilitator and Explaining (SFE) berbantuan alat peraga Dinggram Venn dengan siswa yang mendapatkan model pembelajaran langsung pada materi himpunan kelas VII SMP Negeri 8 Singkawang yaitu dengan hasil rata-rata nilai posttest kelas eksperimen sebesar 82,65 dan kelas kontrol sebesar 61,10. Model pembelajaran Student Facilitator and Explaining (SFE) berbantuan alat peraga Dinggram Venn memberikan pengaruh terhadap kemampuan komunikasi matematis siswa pada materi himpunan kelas VII SMP Negeri 8 Singkawang yaitu sebesar 1,75 dengan kriteria tinggi. Aktivitas belajar siswa selama menggunakan model pembelajaran Student Facilitator and Explaining (SFE) berbantuan alat peraga Dinggram Venn tergolong pada kriteria aktif. Adapun indikator visual activities sebesar $81,42 \%$, indikator oral activities sebesar 75\%, indikator listening activities sebesar $74,15 \%$, indikator writting activities sebesar 79,11\% dan indikator mental activities sebesar 77,35\%. Motivasi belajar siswa tergolong tinggi terhadap model pembelajaran Student Facilitator and Explaining (SFE) berbantuan alat peraga Dinggram Venn dengan pernyataan positif sebesar 4,63 dan pernyataan negatif sebesar 3,98 .

\section{DAFTAR PUSTAKA}

Buyung, B., \& Nirawati, R. (2018). Pengaruh Karakter Kerja Keras terhadap Kemampuan Literasi Matematis Siswa melalui Model Discovery Learning. JPMI (Jurnal Pendidikan Matematika Indonesia), 3(1), 21-25.

Depdiknas. (2006). Permendiknas No. 22 Tahun 2006 tentang Standar Isi untuk Satuan Pendidikan Dasar dan Menengah. Jakarta: Depdiknas.

Hija, A., Nirawati, R., \& Prihatiningtyas, N. C. (2016). Pengaruh Model Pembelajaran Group Investigation (GI) Terhadap Kemampuan Pemecahan Masalah Matematis Siswa Pada Materi Peluang Kelas X MIPA. JPMI (Jurnal Pendidikan Matematika Indonesia), 1(1), 25-33. 
Lestari, K. E, dan Yudhanegara, M. R. (2015). Penelitian Pendidikan Matematika: Panduan Praktis Menyusun Skripsi, Tesis, dan Karya Ilmiah dengan Pendekatan Kuantitatif, Kualitatif, dan Kombinasi disertai dengan Model dan Kemampuan Matemat. Bandung: PT Refika Aditama.

Nurhayati (2016). Pengaruh model pembelajaran Student Facilitator and Explaining(SFE) Terhadap Motivasi Belajar Siswa Di Sekolah Menengah Kejuruan Taruna Satria Pekanbaru. Skripsi. Pendidikan Matematika. Universitas Islam Negeri Sultan Syarif Kasim Riau Pekanbaru. Tidak dipublikasikan.

Parera, E. K. A (2015). Pemanfaatan Papan Berpaku pada pembelajaran Matematika Pokok Bahasan Bangun Datar Materi Menghitung Luas Persegi dan Luas Persegi Panjang Kelas III SD Negeri Timbulharjo Yogyakarta. Skripsi. Universitas Sanata Dharma Yogyakarta. Tidak dipublikasikan.

Prayitno, S., Suwarsono, dan Tatag. (2013). Komunikasi Matematis Siswa SMP Dalam Menyelesaikan Soal Matematika Berjenjang Ditinjau Dari Perbedaan Gender. Seminar nasional Matematika dan Pendidikan Matematika.

Rachmayani, D. (2014). Penerapan Pembelajaran Reciprocal Teaching untuk Meningkatkan Kemampuan Komunikasi Matematis dan Kemandirian Belajar Matematika Siswa. Jurnal Pendidikan UNSIKA, 2(1), 13-23.

Sari, P. A. (2016). Pengaruh model pembelajaran Student Facilitator and Explaining (SFE) terhadap kemampuan komunikasi matematis siswa SMA. Skripsi. FKIP Pasundan University Bandung. Tidak Dipublikasikan.

Siregar, S. (2014). Metode Penelitian Kuantitatif Dilengkapi Dengan Perbandingan Perhitungan Manual dan SPSS. Jakarta: Kencana Prenamedia Group.

Suliswa, S., Rosmaiyadi, R., \& Buyung, B. (2017). Pengaruh Model Pembelajaran Snowball Throwing Terhadap Kemampuan Komunikasi Matematis Siswa. JPMI (Jurnal Pendidikan Matematika Indonesia), 2(1), 37-41

Wahyuni, R . Utami, C. Husna, N. (2016). Pengaruh Model Role Playing Terhadap Kemampuan Komunikasi Matematis Siswa Pada Materi Fungsi Komposisi Kelas XI SMA Negeri 6 Singkawang. Jurnal Pendidikan Matematika, 1(2), 81-86.

Wiradnyana (2014). Pengaruh Model Pembelajaran Student Facilitator and Explaining (SFE) terhadap Kemampuan Pemecahan Masalah Matematis Siswa. Jurnal Mimbar PGSD Universitas Pendidikan Ganesha, 2(1), 1-12.

Zahra, C. Widyawati, S. Ningsih. E. F. (2017). Eksperimentasi Model Pembelajaran Kooperatif Tipe Student Facilitator and Explaining (SFE) Berbantuan Alat Peraga Kotak Imajinasi Ditinjau dari Kecerdasan Spasial. Jurnal Ilmiah Pendidikan Matematika, 2(2), 97-104. 